\title{
The Influence of Existing Knowledge on the Student Cognitive Understanding Process in Mastering the Malaysian Economics Text Reading
}

\author{
Ab Aziz Ab Samad, Nor Aishah Buang \& Muhammad Hussin
}

To Link this Article: http://dx.doi.org/10.6007/IJARBSS/v11-i3/8932

DOI:10.6007/IJARBSS/v11-i3/8932

Received: 03 January 2021, Revised: 06 February 2021, Accepted: 25 February 2021

Published Online: 12 March 2021

In-Text Citation: (Samad et al., 2021)

To Cite this Article: Samad, A. A. A., Buang, N. A., \& Hussin, M. (2021). The Influence of Existing Knowledge on the Student Cognitive Understanding Process in Mastering the Malaysian Economics Text Reading. International Journal of Academic Research in Business and Social Sciences, 11(3), 286-300.

Copyright: @ 2021 The Author(s)

Published by Human Resource Management Academic Research Society (www.hrmars.com)

This article is published under the Creative Commons Attribution (CC BY 4.0) license. Anyone may reproduce, distribute, translate and create derivative works of this article (for both commercial and non-commercial purposes), subject to full attribution to the original publication and authors. The full terms of this license may be seen

at: http://creativecommons.org/licences/by/4.0/legalcode

Vol. 11, No. 3, 2021, Pg. 286 - 300

Full Terms \& Conditions of access and use can be found at http://hrmars.com/index.php/pages/detail/publication-ethics 


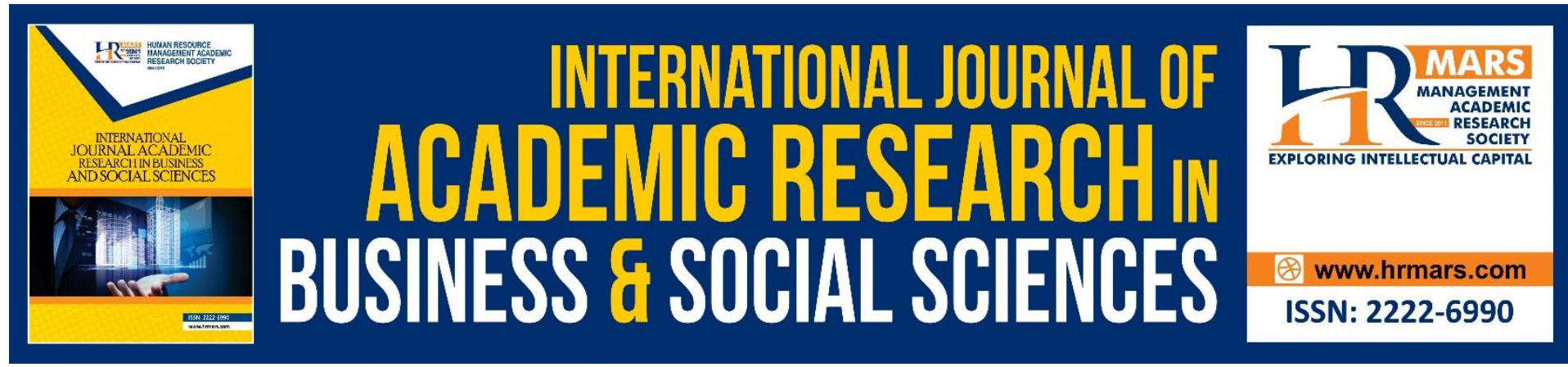

\title{
The Influence of Existing Knowledge on the Student Cognitive Understanding Process in Mastering the Malaysian Economics Text Reading
}

\author{
Ab Aziz Ab Samad, Nor Aishah Buang \& Muhammad Hussin \\ Universiti Kebangsaan Malaysia
}

\begin{abstract}
Schemata are existing knowledge structures or previously acquired knowledge structures that are stored in the memory. Whereas cognitive processing is a process that involved managing the mental activities that occurred in the students' mind to process information so that information can be stored and recalled. The objective of this study was to explore the impact of existing knowledge on cognitive processes such as attention, perception, training, coding and recalling of students in mastering the textual content of the Malaysian Economics through reading process. This study used qualitative design that combined two methods: interview and document content analysis. Purposive sampling was used in this study. The study sample consisted of four pre-university students taking Malaysian Economics papers in the Malaysian Higher School Certificate (STPM) in Johor Bahru district. The findings showed that the influence of existing knowledge on the processes of attention, perception, training, coding and recalling performed by students to master the textual reading of the Malaysian Economics. Therefore, the findings of this study could be practiced by students to master the information read from various sources.

Skemata merupakan struktur pengetahuan sedia ada atau struktur pengetahuan yang diperoleh sebelumnya yang tersimpan dalam ingatan. Manakala proses kognitif pemahaman merupakan proses yang melibatkan pengelolaan aktiviti-aktiviti mental yang berlaku dalam minda pelajar bagi memproses maklumat agar maklumat dapat disimpan dan diingati semula. Objektif kajian ini adalah menerokai pengaruh pengetahuan sedia ada ke atas proses kognitif pemahaman iaitu perhatian, persepsi, latihan, pengekodan dan pengingatan semula yang berlaku ke atas pelajar dalam menguasai kandungan teks Ekonomi Malaysia melalui proses membaca. Kajian ini menggunakan reka bentuk kualitatif yang menggabungkan dua kaedah iaitu temu bual dan analisis kandungan dokumen. Persampelan bertujuan digunakan dalam kajian ini. Sampel kajian terdiri daripada empat orang pelajar prauniversiti yang mengambil kertas Ekonomi Malaysia di peringkat Sijil Tinggi Persekolahan Malaysia (STPM) di daerah Johor Bahru. Dapatan kajian menunjukkan wujud pengaruh pengetahuan sedia ada ke atas proses perhatian, persepsi, latihan, pengekodan dan pengingatan semula yang dilakukan oleh pelajar untuk menguasai bacaan teks Ekonomi Malaysia. Justeru itu, dapatan kajian ini boleh dipraktikkan oleh pelajar untuk menguasai maklumat yang dibaca daripada pelbagai sumber informasi.
\end{abstract}




\section{Introduction}

These are the analysis report of STPM examination results of Economics subjects for Microeconomics, Macroeconomics and Malaysia Economics in 2016 to 2018. The analysis of Microeconomics subject for term 1 showed the trend of low and inconsistent percentage of full pass candidates which showed an increments of $8.50 \%$ in 2017 and a decrement of $4.53 \%$ in 2018. Meanwhile, the analysis of Macroeconomic subject for the second term showed that the percentage trend of the full pass candidates were also low and inconsistent with an increase of $0.69 \%$ in 2017 and a decrease of $2.71 \%$ in 2018. Similarly, the analysis of the Malaysia Economics subject for the third term showed a low percentage trend of full pass candidate with a decrement by $5.71 \%$ and $0.18 \%$ in 2017 and 2018 respectively. In addition, the repeat examination report for the Malaysia Economics subject in 2015 showed that the percentage of failed candidates was $58.09 \%$, which exceeded the percentage of full pass candidates by $16.63 \%$ (MPM, 2015-2018). In this regard, the low percentage of full pass candidates indicated that there are problems with students' mastery of the Economics subject, especially for the subject of Malaysia Economics. This is because, part of the objectives of examinations are to identify the extent to which students master the textual content of a subject. If student achievement is at a low level, then this situation indicates that the level of students' mastery of textual content does not meet the targets required in the Economic Syllabus.

The literature reviews showed that students' mastery and achievement of a subject is influenced by various factors. In the field of economic education, the study of Zulkifli et al. (2014) showed that the existing economics knowledge and mathematical skills influenced graduate achievement in Macroeconomics courses at UPSI. Meanwhile, a study by Chen and Lin (2015) at a public university in Taiwan found that peer factors and student attendance had a significant effect on the academic performance of college students for Microeconomics courses. Similarly, Mulki's (2019) study which looked at the influence of variables such as family, teaching staff, university environment, student involvement in campus activities, and learning motivation influenced student achievement in Economics subjects. However, this study only looked at the problems that affected the dependent variables and the students' academic achievement, without exploring the way in which the student processes information from the textual structure that affect the level of understanding and mastery of textual content, thus increasing the level of achievement. According to Meyer's (1985) Prose Analysis Model, for a student to be successful, he or she needed to first understand the structure of the text. This is important because the structure of the text is one of the foundations of the schemata. Students will look for text schemata to help them understand the textual reading. This schemata then served as a guideline of the students to understand and master textual reading.

In this regard, the MOE's Curriculum Development Center (Pusat Pembangunan Kurikulum, PPK) in 2005 has produce a textual guidance that contain examples of teaching preparation using active learning pedagogy in the teaching and learning process. PPK (2006), The Active Learning Practice Guide for Basic Economics was produced and tested in several states in order to identify the suitability and effectiveness of active learning activities for teachers, students and students' academic achievement in mastering the subject. In the field of economic education, active learning pedagogies such as the use of web-based portals, a variety of teaching and learning techniques and materials, are always featured in the 
literature in order to actively involve students and for them to gain benefits from its impact in terms of mastery and achievement of the subject. However, although there are studies that focused on active learning pedagogy, studies on the exploration of student understanding schemes as a result of the implementation of active learning pedagogy should be given due attention. This is because, according to Bartlett's (1932) schemata theory, students' existing knowledge plays an important role in organizing, encoding and recalling important information stored in memory. Schemata theory in the context of text understanding has been introduced by Rumelhalt (1980) as a form of mental framework, which explains the important role of the existing knowledge in understanding and mastering textual content in order to produce a meaningful knowledge (Santrock, 2018).

Therefore, the term how refers to the cognitive process, that is, how mental activities occur on students in processing information received from the content of the text, so that information can be understood and remembered. Eggen and Kauchak (2016), in the processing of information to form a meaningful knowledge, the new information received will be integrated with the existing knowledge. However, according to Yusoff (2015), there is an inequality between the text content and the existing knowledge that will affect the level of students' understanding of the content of the text. This situation happened when the appropriate schemata failed to be activated when the student is trying to understand the text, thus some new information cannot be created at that time. As a result, students will have difficulty in understanding and mastering the content of the text. Rumelhart (1980), in the schemata of text reading comprehension theory asserts, when students have an appropriate existing knowledge, but there is no relationship between text content and the existing knowledge, then this situation will cause students to incorrectly process information by building inaccurate understanding of textual content. Therefore, Rumelhart argues that students need helps to activate the existing knowledge related to the text and to facilitate the cognitive processing of new information in order to understand and master the reading of the text content. A study by Abdul Rahman et al. (2017) shows that students who activate the existing knowledge related to the content of the text they learned, will be able to process information to strengthen their level of understanding of the textual content. Similar finding can be seen in the study of Kendeou and Van Den Broek (2007), which explores the influence of existing knowledge on cognitive processes in understanding the content of scientific texts. Participant achievement is assessed based on the protocol of recalling textual information. The results show that there is an influence of existing knowledge on the reading and mastery of text content. As a result of this problem, questions such as; is there an influence of existing knowledge on the cognitive process of student understanding in mastering text reading?; how does the influence of existing knowledge function and affect the cognitive process of students' reading comprehension of text?; and what are the cognitive process of text reading understanding performed by students as a result of the influence of the existing knowledge?.

\section{Research Questions}

In particular this study attempted to answer the following questions:

1. Is there an influence of the existing knowledge on students' attention process in mastering the textual reading?

2. Is there an influence of existing knowledge on students' perceptual processes in mastering the textual reading? 
3. Is there an influence of the existing knowledge on students' training process in mastering the textual reading?

4. Is there an influence of existing knowledge on students' coding process in mastering the textual reading?

5. Is there an influence of the existing knowledge on students' process of recalling in mastering the textual reading?

\section{Literature Review}

The schemata theory is one of the leading theories of cognitive learning and was introduced by Bartlett in 1932. The schemata were then introduced in reading by Rumelhalt in 1980, when discussing the important role of existing knowledge in reading comprehension. Rumelhart defined schemata as a data structure to represent genetic concepts stored in memory. It is a cognitive building block covering all areas of knowledge, experiences, feelings and events. According to Santrock (2018), the schemata is a theoretical framework that described how existing knowledge processed, interpreted and understood the new information gained to produce more a meaningful information. It is acknowledged that Clark and Mayer (2011) that new information entered into memory will be integrated with existing knowledge. This is because before new information is stored in memory, existing knowledge related to new information would be consolidated to form new knowledge. Subsequently, according to Eggen and Kauchak (2016), this new knowledge would go through the process of preparation and integration to make the new knowledge more meaningful. Thus, Bartlett (1932) and Rumelhart (1980) asserted that the knowledge structures known as the existing knowledge or the previously acquired knowledge structures and stored in memory are known as the schemata.

In the field of cognitive psychology, schemata theory had the advantage of describing the structure of existing knowledge stored in memory and how this existing knowledge is constructed, structured and used in the understanding and mastery of textual content. The schemata will change as new information becomes available and will be rearranged in a more meaningful way. Each student has schemata for information. While the schemata for information is different from one student to another. It is recognized by Anderson (1985) that students' existing knowledge played an important role in understanding and mastering the textual content, and this knowledge is different for each student based on their experience. According to Nair and Muthiah (2005), students will be able to develop concepts in their cognitive structure with their existing knowledge.

However, if a student does not have existing knowledge of the textual content being read, then that knowledge will be built on the other knowledge that he or she had in order to develop a new schema that will help him or her master the reading of the text. This is acknowledged by Nair and Arumugam (2006), if the student does not have the existing schemata for the textual content he or she received, the student will develop new schemata based on the existing ones in order to understand the content of the text. On the other hands, if the information that the student read is new knowledge, the student will likely combined two or more schemata in order to understand and master the content of the text. Rumelhart and Norman (1978) said that, the construction of the new schemata is known as 'restructuring'. The study of Mailok et al. (2012) focused on visualization methods in the 
exploration of map learning and how their assessment was made in improving students' cognitive processes. The visualization of exploration focused on how students went through the processes of building new information in the mind from the beginning of the observation process towards the new information building activities that took place in their minds. The results of this study demonstrated that mastery of the visualization method of exploration can enhance students' mastery of the textual content taught.

In addition, in the processing of information to improve the understanding and mastery of textual reading, according to Ahmad (2010), it involved two stages of cognitive processes namely basic cognitive processes and high level cognitive processes. The basic cognitive stages included the perception-making process that involved the conceptualization and construction of concepts and processes of memory such as information processing. Meanwhile, high level cognitive processes involved the processes of reasoning, decision making, problem solving, understanding and meta-cognition. These two stages are related to each other and are not separated. However, for Eggen and Kauchak (2016) there are five cognitive processes that include attention, perception, training, encoding and recalling. According to Fetsco and McClure (2005), the process of attention refers to the process of selecting important information, and it depended on the existing knowledge of students (Cook \& Mayer, 1988). This is acknowledged by Woolfolk (2016), by paying attention to the selected information, what is observed will be processed to a certain degree depending on the existing knowledge and new information he or she wished to learn from the reading. Meanwhile, the perception process according to Slavin (2018) involved mental interpretation, which influenced by mental state, existing knowledge, experience and other factors. Meng (2003), students who do not have existing knowledge about a perception will not be able to convey the meaning. Eggen and Kauchak (2016), this is because perceptual accuracy in learning activities is important. Next, the training process according to Santrock (2018) is the process of repeating new information from time to time until the information remained in the memory. This is supported by Slavin (2018) to retain new information in the memory is to think through it or repeat it over and over again. For the coding process, Eggen and Kauchak (2016) stated that it is the process of arranging information in the memory. It is the process by which the information being read is translated and compiled in an acceptable form of memory. Santrock (2000) this form represented the observed object and depended on the students' existing knowledge. According to Eggen and Kauchak (2016) one of the most effective coding strategies to generate more meaningful information is through the activation of existing knowledge (schema activation). Subsequent recall processes according to Woolfolk (2016) are processes of retrieving information from the memory. It is an act of finding information or knowledge already stored in the memory for information purposes. The extent to which the accuracy of existing knowledge is retained in memory is dependent on the memory system (Mok, 2009).

\section{Methodology}

This study was conducted using a qualitative research design. The researchers wanted to find answers to the impact of existing knowledge on students' cognitive processes in mastering the reading of the Malaysian Economics texts. The data collection method used was interview and document content analysis. The interviews conducted were semi-structured while the content analysis of the document was used to reinforce the findings. The selection of this semi-structured interview was in accordance with the opinion of Chua (2011) and Gall et al. 
(2003), which was to obtain more uniform and in-depth information from the study participants. To make this study more meaningful, the researcher had chosen a qualitative research design in the form of a case study. Descriptive case study was the case study design used in this study. The study sample consisted of four pre-university students who took the Malaysian Economics papers specially selected in accordance with this study.

\section{Findings}

From the analysis of the interviews, there was an influence of existing knowledge on the cognitive processes that students undertook to master the reading of the texts. In the process of attention, it was found that S3 and D4 students were able to identify and select important information from reading the text using their existing knowledge. This situation occurred when students observed the text characteristics before the text reading process was completed. This was stated by students S3 and D4 as follows:

"To my knowledge, when the word is bolded, it indicates that it is important. ... By observing this darkened word, I can easily identify important facts ..."

$$
\text { (TB PKP - 108.S3 - pg 33) }
$$

"...usually what I know, when the information is bolded, it means that the information is important, ...I will focus on that information"

$$
\text { (TB PKP - 110.D4-pg 44) }
$$

The findings also showed that students $\mathrm{M} 2$ and D4 would highlight important information while reading the text by using highlighters to isolate important facts with supporting information. This behavior was already a habit for them when they read the texts. This was stated by students M2 and D4 as follows:

"Usually I will use highlighter pens of various colors to highlight important facts ..." (TB PKP - 120.M2 - pg 22)

"...I usually use a highlighter pen to mark the facts that I find important while reading." (TB PKP - 116.S3 - pg 34)

In addition, on in the perception process, it was found that studentsL1 and D4 had misinterpreted the information they read, making them inaccurate. This situation occurred because they did not have existing knowledge regarding the information. This was stated by students L1 and D4 as follows:

"...I have no existing knowledge of the topic and therefore misinterpreted the information.." (TB PKP - 144.L1 - pg 12)

"...I think my existing knowledge of the information is still inadequate."

$$
\text { (TB PKP - 124.D4 - pg 46) }
$$

Therefore, in order to interpret the information they read to be an accurate or easy-tounderstand meaning, the actions taken by students S3 and D4 based on the existing 
knowledge was to focus on auditory and graphic materials that were the textual features when reading the texts. Through the textual features, it allowed the information they read to be linked to the existing knowledge to produce information that was easy to understand. This was stated by students S3 and D4 as follows:

"....I'll focus on the features of the text because I know the bolded words, tables or diagrams, ... it's easier for me to interpret the information I read..."

$$
\text { (TB PKP - 124.S3 - pg 35) }
$$

"....usually I will focus on the textual features such as the summary of information in tables, diagrams, bolded information. ... as I read, I could understand and interpret the information easily." (TB PKP - 124.D4 - ms 46)

Next, in the training process, it was found that students L1 and M2 used their existing knowledge to increase their level of mastery of the information being read by repeatedly reading the text. By re-reading the content of the text, the quantity and quality of the information read would increase and remained in memory. This was stated by students L1 and $\mathrm{M} 2$ as follows:

"What I always do,... I will reread the contents of the textbook to make it easier for me to remember the information I have read before." (TB PKP - 148.L1 - pg 12)

"To increase my mastery over the information I read, the same thing I did was doing the exercise and reread the textbook content over and over again.."

$$
\text { (TB PKP - 134.M2 - pg 23) }
$$

In addition to repeated readings of the texts, the findings indicated that students L1 and D4 had taken action to memorize information that seemed important and needed to be remembered. Memorizing information was one of the things they always practiced to keep that information in mind. Students L1 and D4 stated this:

"To keep the information I have read so it is easy to remember ... I'll memorize every single one of it..." (TB PKP - 150.L1 - pg 12)

"Usually I will read and memorize the information over and over again ..."

$$
\text { (TB PKP - 130.D4 - pg 46) }
$$

Besides, in the coding process, through the knowledge available to L1 and M2 students, they were able to organize information being read by categorizing it into various textual features such as diagrams, mind maps, tables, symbols, charts, and information framework. This is done so that the information read can be translated and compiled in a way that was understandable and memorable. This was stated by students L1 and M2 as follows:

"Usually what I do, I use mnemonic techniques, tables, information frameworks, mind maps and diagrams ... I have some existing knowledge of how to do it ... it's easy to understand and recall that information." (TB PKP - 156.L1 - pg 13) 
“...no problem, ... to create mind maps, diagrams and mnemonic techniques, this knowledge I have gained from previous teachers ....so, that is easy for me to remember what I read" (TB PKP - 144.M2 - pg 24)

Furthermore, for the recalling process, it was found that student $\mathrm{S} 3$ had used the mnemonic techniques he had previously learned to facilitate him to recall the important information contained in the texts. The findings of the document analysis showed that there were several techniques that students used when making notes such as keyword, acronyms and loci techniques. For example, student $\$ 3$ had used acronym technique by writing some initial letter combinations to help him recalled information about the use of consumer price index information. The acronym technique information recorded by S3 was;

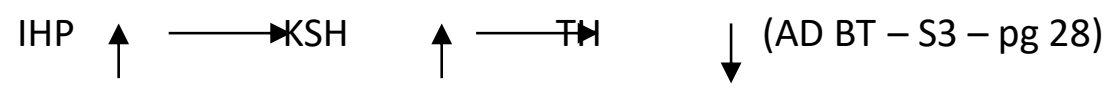

Based on this acronym technique information, it enabled S3 to rethink the use of consumer price index (IHP) to measure the cost of living (KSH) and standard of living (TH) of the households. As the consumer price index rises, inflation rates rise. As a result, the cost of living is increasing because with the same amount of money, quantity of goods capable to be purchased is reduced. This showed that the standard of living is declining.

Moreover, for students M2 and D4, answered the exercise questions in the textbook to allowed them to recall important information they had previously read. This was because when students answer a question, they were able to link the existing knowledge of that information with the newly acquired information to produce more meaningful and accurate new knowledge. In addition, questions were among the features of the text that enabled students to recall information or existing knowledge stored in memory. This was stated by M2 and D4 students as follows:

"...increasing the exercise in the textbook ... to make it easier for me to recall the information I've read" (TB PKP - 146.M2 - pg 24)

"...and then I will do a review exercise based on the information I have read and learned." (TB PKP - 142.D4 - pg 47)

\section{Discussion}

The results showed that there is an influence of existing knowledge as students did the process of identifying and selecting important information obtained from reading the text. The influence of the existing knowledge occurred when students performed an observation activity on the features of the text before the reading of the text. This act seemed to indicate that students were aware of the importance of the textual features that could increase their attention in identifying and selecting important information contained in the text. According to Nachiappan et al. (2009) bold and italic text, tables, diagrams, symbols, examples, summaries at the end of the chapter, as well as questions and answers at the end of the chapter are among the features of the text, which students should pay attention to. It is recognized in Dembo (2004), before reading a textbook; students need to scan the text to identify the textual features present in the textual content. This is because paying attention 
to the textual features can help students increase their attention in identifying and selecting important facts and provided supporting information when reading the text. According to Mayer (1984) students who pay attention to the features of the text can easily select important information in the text content. Therefore, through existing knowledge, students can increase their attention to the text information they will read. According to Woolfolk (2016) existing knowledge will help students increase their attention to something they read. This is because they are able to identify and select important content better than students who do not have existing knowledge of the text. This is supported by Cook and Mayer (1988), students who have the existing knowledge will be able to select important information from the text. Indirectly, according to Ruddell (2005) students with the existing knowledge will be able to easily understand and well mastered the textual content being read.

In addition, the findings also indicated the influence of existing knowledge when students engaged in highlighting activities as important information is selected from the reading of the text. This action is intended to build and enhance existing knowledge of the content of the text. According to Mayer $(1984,1999)$ to assist students who do not have the existing knowledge of the textual content, attention should be given to the gestures in the text, which indicate important information is read to facilitate the text selection process. Students can provide important alerts in the text by bolding, underlining, or giving bullet marks to the information. The findings showed that students had used a variety of colored pens while highlighting the reading information. The highlighting of important information through colored pens showed students work to build and improve their existing knowledge, so that it would be easy to identify and select important information, and to reinforce their memory in recalling information when repeating the text readings.

Furthermore, the study found that the influence of existing knowledge on students' perceptual processes, which means the process of interpreting information obtained from reading texts. The findings showed that when a student lacks existing knowledge or inadequate knowledge about what is being read, the result is that the students will interpret the information inaccurately. This is because students are unable to grasp the information they are reading and often misinterpret it to give an inaccurate sense of meaning. According to Rumelhart (1980) if students do not have existing knowledge that is relevant to the content of the text they are reading, it will result in the reader developing incomplete or inaccurate understandings. It is acknowledged by Salvin (2018) that students who do not have existing knowledge of a given perception will not be able to interpret it accurately.

However, the findings showed that when reading a text, there is an influence of existing knowledge on students as they focused on the auditory and graphic materials that are the features of the text. This is because textual features contain important information that is bolded, in italic, or underlined that students could pay attention to when reading the text. In addition, there are the summaries of important contents and supporting information in a variety of graphics such as tables, diagrams, charts, graphs, symbols and mind maps; all of which enabled students to interpret the information accurately. The results of Gilder's (2009) study showed that when students are trained in information processing strategies based on text characteristics, their level of understanding of the content of the text structure being read increased. At the same time, it reduced the error which resulted in inaccurate perceptions when reading the text. Similarly, the findings of Buang's (1995) study showed 
that when students are unable to identify key ideas and supporting ideas in textual content and answering questions related to textual features, it will impact students' level of understanding and achievement.

Moreover, the study found that the influence of existing knowledge on students' training process that is the process of repeatedly reading textual information over and over again. The findings showed that the process of reading texts repeatedly had been practiced by students both at home and at school. At school before teachers teach, students will read the texts. This action is to build and enhance the existing knowledge of the topics that the teacher will address for clarity. According to Rumelhart (1980), students need to activate their existing knowledge to facilitate the mastery of new information and to assist them in the process of understanding the content of the text they have read. Next, when students are conducting a group discussion, they will read the text to find important content for discussion in the group. Thus, as the teaching and learning process took place, the process of repetition of information through text reading was done again. According to Eggen and Kauchak (2016) the repetition of information is known as a retention exercise that is used to retain new information in memory. While at home, in order to ensure that the important information learned at school is retained, students will repeat the reading of the text. According to Santrock (2018) if the process of information retrieval is carried out from time to time, the information will remain in the memory. Bromage and Mayer (1986), repeated reading of the text can increase students' mastery of the information they read. This is due to an increase in the quantity and quality of information stored in the memory.

In addition, the findings also showed the influence of existing knowledge when students practiced the process of information retrieval through verbal or physical information memorization techniques. Based on the existing knowledge, verbal information memorization techniques occurred when students repeated the same information over and over again in a loud voice or in their mind. Physically, the technique of memorizing information occurred when students repeatedly write information or draw the same diagram on paper. This is done by the student so that the information repeatedly mentioned or written over and over can be stored and retained in memory. Often, information that the students memorized is the important information such as key content, diagrams, formulas and so on. It is acknowledged by Bromage and Mayer (1986) that the types of information retained through the process of repetition are important information. The findings also showed that students prefer to memorize information by repeatedly mentioning and writing the same information over and over while reading the text. However, keep in mind that when implementing these two memorization techniques, students are advised to first understand the information clearly.

Besides, the findings showed that there is an influence of existing knowledge as students undertake the coding process, which is the process of compiling information in the memory. The findings showed that with the existing knowledge, students compiled the information that they read in various categories such as mind maps, diagrams, tables, symbols, information frameworks and charts. Organizing information in this form of categorization makes it easier for them to understand, memorize, and recall the information they read. Meanwhile, the findings also showed students' favorite organization of information is in the form of mind maps compared to other forms of categorization. This is because the 
findings of Tee et al. (2009) showed how information organized in the form of a mind map helped the students easily take notes and recalled the information. In addition to compiling information in this form, it combined and balanced the use of the right and left brain during learning. Similarly, the results of the study of Wong \& Sharaai (2012) found that the formulation of information in the form of mind maps can enhance students' memory, achievement and interest in learning in a particular subject.

Furthemorer, the findings showed that there was an influence of existing knowledge as students did the process of recalling, which means the process of retrieving information from memory. The finding showed that through the existing knowledge, students did the process of recalling through the use of mnemonic techniques which are acronym, keyword and loci techniques. These techniques are one of the features of texts that helped students integrate new information with meaningful images or contexts that enhanced student memory. According to Nachiappan et al. (2009), there are a number of mnemonic techniques that enabled students to recall information stored in memory such as loci techniques, keywords, connective words, rhymes, acronyms, chunking and more. The findings of Muhammad 's (2017) study showed that the use of mnemonic techniques among students can improve memory input, reduce mental stress and help expand the scope of memory to a maximum. Similarly, the results of Tang's (2005) study found that the use of mnemonic techniques among students can help them to recall the facts more effectively and facilitate students' practice of reviewing. In addition, the findings also showed that the use of mnemonic techniques can elicit students' creativity.

In addition, the findings also showed the influence of existing knowledge when students performed the recall process by answering the exercise questions contained in the textbook. When they finished reading the text, students will try to answer the exercise questions at the end of the chapter in order to test the extent to which existing knowledge and the new information can help them recall the text information stored in memory. Usually, students will practice by answering questions related to the information they read. Students who are able to answer the questions by having the correct answer proved that they have been able to recall important information from reading the text. This situation indicated that students have been able to understand and master the text. Similarly, for students who answered the question by giving the wrong answer, this indicated that the student is unable to recall the information they read. At the same time, it proved that the students do not yet understand and master the content of the text. According to Mayer (1993) questions are textual features that can help students integrate new information with the existing knowledge. Through questions, students are able to recall the information contained in the text. At the same time, the questions determined whether students understand and master the reading of the texts or not.

\section{Conclusion}

In a nutshell, this exploration gives students a clearer picture of the extent to which existing knowledge influences their cognitive processes through which they understand and master the reading of the text. Students can also apply the textual content mastery to other subjects using the same method. The findings of this study can serve as a guide for students to enhance their cognitive abilities through existing knowledge in order to facilitate students' 
understanding and mastery of learning information, engage students in learning, and further enhance academic achievement in related fields.

\section{References}

Abdul Rahman, A., Mahyuddin, M. K., Jamali, H. N., Ku Azizan, K. F., \& Mat Isa, S. N. (2017). Teori skemata melalui penguasaan bahan bacaan: Satu proses interaktif. Jurnal Sultan Alauddin Sulaiman Shah, 1, 82-92.

Ahmad, R. (2010). Model pemprosesan maklumat kognitif dan pembuatan keputusan. Teori dan amalan dalam sistem penilaian prestasi pekerja sektor awam di Malaysia, International Journal of Management Studies 17 (2), 201-224.

Anderson, R. C. (1985). Role of readers schema in comprehension, learning and memory. In R. B. Ruddell, M. R. Ruddell \& H. Singer (Eds.) Theoretical models and processes of reading (pp. 469-82). International Reading Association.

Bartlett, F. C. (1932). Remembering: A study in experimental and social psychology. Cambridge University Press.

Bromage, B. K., \& Mayer, R. E. (1986). Quantitative and qualitative effects of repetition on learning from technical text. Journal of Educational Psychology 78 (4), 271-278.

Buang N. A. (1995). An investigation on how the Malaysian beginning Economics student cognitively process chapter one of a Microeconomics textbook: Implication for the teaching of reading and rewritting the chapter. [Unpublished doctoral dissertation] Indiana University.

Chen, J., \& Lin, T. (2015). Effect of peer attendance on college students' learning outcomes in a microeconomics course. The Journal of Economics Education 46 (4), 350-359.

Chua Y. P. (2011). Kaedah dan statistik penyelidikan. Kaedah penyelidikan. Mc Graw Hill Education (Malaysia) Sdn. Bhd.

Clark, R. C., \& Mayer, R. E. (2011). e-Learning and the science of instruction, proven guidelines for consumers and designers of multimedia learning. Pfeiffer.

Cook, L. K., \& Mayer, R. E. (1988). Teaching readers about the structure of scientific text. Journal of Educational Psychology, 80, 448-456

Dembo, M. H. (2004). Motivation and learning strategies for college success: A selfmanagement approach. Lawrence Erlbaum Associates.

Eggen, P., \& Kauchak, D. (2016). Educational psychology. Windows on classrooms. Pearson Education, Inc.

Fetsco, T., \& McClure, J. (2005). Educational psychology. An integrated approach to classroom decisions. Pearson Education, Inc.

Gall, M. D., Gall, J. P. \& Brog, W. R. (2003). Educational research: An introduction. Allyn and Bacon.

Gilder, J. (2009). Are you gonna make us read outta the book this year Mr. Gilder? The effects of teaching text structure on reading comprehension of informational texts. (Publication No. 1470235) [Master's thesis, University of California]. Pro Quest LLC.

Kendeou, P., \& Van Den Broek, P. (2007). The effects of prior knowledge and text structure on comprehension processes during reading of scientific texts. Memory \& Cognition 35 (7), 1567-1577.

Mailok, R., Osman, M., Ubaidullah, N. H., Fabil, N., \& Hassan, H. (2012). Keberkesanan kaedah visualisasi penjelajahan terhadap prestasi pelajar dalam pembelajaran peta menggunakan google earth. Kertas Kerja Seminar Kebangsaan Majlis Dekan Pendidikan IPTA 2012. The Zon Regency. Johor Bahru, Johor. 7-9 Oktober. 
Majlis Peperiksaan Malaysia. (2015-2018). Laporan tahunan. Affluent Master.

Mayer, R. E. (1984). Aids to text comprehension. Journal Educational Psychologist 19, 42

Mayer, R. E. (1999). Designing instruction for constructivist learning. In C. M. Reigeluth (Ed.) Instructional-design theories and models: Volume II. A new paradigm of instructional theory, (pp. 141-160). Lawrence Erlbaum Publishers.

Mayer, R. E. (1993). Problem-solving principles. In M. Fleming \& W. H. Levie (Eds.), Instructional massage design: Principles from the behavioral and cognitive science, (pp. 253-282). Educational Technology Publications.

Meng, E. A. (2003). Psikologi pendidikan II. Penerbit Fajar Bakti Sdn. Bhd.

Meyer, B. J. F. (1985). Prose analysis: Purposes, procedures, and problems. In B. K. Britton \& J. B. Black (Eds.), Understanding Expository Text. A Theoretical and Practical Handbook for Analyzing Explanatory Text (pp. 11-64, 269-304). Lawrence Erlbaum Publishers.

Mok, S. S. (2009). Psikologi pendidikan untuk pengajaran \& pembelajaran. Penerbitan Multimedia Sdn. Bhd.

Muhammad, M. (2017). Teknik mnemonik sebagai strategi kognitif dalam meningkatkan keupayaan ingatan pelajar peringkat pengajian pra-u: sorotan kajian lepas. National Pre University Seminar 2017, RHR Hotel. Kajang Selangor, 23 Ogos.

Mulki, S. N. (2019). The influence of learning motivation on student achievement studying economics at mahadika ciracas vocational high school. Literatus Journal 1 (1), 10-13.

Nachiappan, S., Kamaruddin, K., Abd Shukor, A. A., Jantan, R., Mustapha, R., \& Hamzah, H. (2009). Pembelajaran dan perkembangan pelajar. Oxford Fajar Sdn. Bhd.

Nair, S., \& Arumugam, R. (2006). Keberkesanan kaedah model skema bagi meningkatkan kefahaman dan minat pelajar terhadap cerpen Bahasa Melayu. Malaysian Journal of Learning and Instruction, 3, 65-92.

Nair, S., \& Muthiah, M. (2005). Penggunaan model konstruktivisme lima fasa Needham dalam pembelajaran sejarah. Jurnal Pendidik dan Pendidikan, 20, 21-41.

Pusat Perkembangan Kurikulum. (2006). Laporan kajian rintis buku panduan pembelajaran aktif dalam Ekonomi Asas. Putrajaya: PPK, Kementerian Pendidikan Malaysia.

Ruddell, M. R. (2005). Teaching content reading and writing. John Wiley \& Sons, Inc.

Rumelhart, D. E., \& Norman, D. A. (1978). Acceretion, tuning and restructuring: Three models of learning. In R. C. Anderson, R. J. Spiro \& W. E. Montaque (Eds). Semantic factors in cognition. Lawrence Erlbaum Publishers.

Rumelhart, D. E. (1980). Schemata: The building blocks of cognition. In J. Rand, C. Betram, \& W. E. Brewer (Eds.). Theoretical issues in reading comprehension. Lawrence Erlbaum Publishers.

Santrock, J. W. (2000). Psychology. McGraw-Hill.

Santrock, J. W. (2018). Educational psychology. McGraw-Hill.

Slavin, R. E. (2018). Educational psychology. Theory and practice. Pearson Education, Inc.

Tang G. L. (2005). Meningkatkan keupayaan pelajar mengingat fakta sejarah dengan menggunakan kaedah mnemonik. Seminar Penyelidikan Tindakan Tahun 2005. Pejabat Pelajaran Gabungan Bahagian Sri Aman dan MP Batu Lintang. Kuching, Serawak. 3-4 Oktober.

Tee, T. K., Yunos, M. J., Mohamad, B., Othman, W., \& Yee, M. H. (2009). Penilaian aras kemahiran berfikir menerusi ujian SEA, rubrik kemahiran berfikir dan rubrik peta minda. Kertas Kerja Persidangan Kebangasaan Pendidikan Sains Dan Teknologi 2009. Dewan 
Tunku Ibrahim Ismail, Universiti Tun Hussein Onn Malaysia. Batu Pahat, Johor. 26-27 Oktober.

Wong L. S., \& Sharaai A. H. (2012). Penggunaan peta minda untuk meningkatkan daya mengingat dan minat mengulang kaji bagi pelajar tahun 4 dalam topik pembiakan tumbuhan. Kertas Kerja Persidangan Kebangsaan Pembangunan dan Pendidikan Lestari 2012. Institut Pendidikan Guru Kampus Tuanku Bainun, Bukit Mertajam Pulau Pinang. 9-10 September.

Woolfolk, A. (2016). Educational psychology. Active learning. Pearson Education, Inc.

Yusoff, M. (2015). Strategi pengajaran bacaan dan kefahaman. PTS Akademia.

Zulkifli, N., Abdul Aziz, S. N., \& Zakariya, Z. (2014). Pengaruh pengetahuan asas ekonomi dan kemahiran matematik terhadap pencapaian siswazah upsi dalam kursus makroekonomi. e-Proceeding of the World Conference on Integration of Knowledge. Golden Flower Hotel, Bandung, Jawa Barat, Indonesia. 15-16 September. 